\title{
COMPARISON OF FINANCIAL PERFORMANCE OF PRIVATE COMMERCIAL BANKS IN PAKISTAN
}

\author{
Muhammad Baqir \\ MBA Student \\ Business Administration, Art \& Social Sciences \\ University of Education Lahore, Pakistan \\ E-mail: baqiralisiddique@ gmail.com \\ Sajid Hussain \\ MBA Student \\ Department of Business Administration \\ Bahauddin Zakariya University Multan, Pakistan \\ E-mail: sajid.hussain6441@gmail.com \\ K. M. Anwarul Islam \\ Associate Professor \\ Department of Business Administration \\ The Millennium University, Dhaka, Bangladesh \\ PhD Candidate \\ University of Selangor, Malaysia \\ E-mail: ai419bankingdu@gmail.com

\section{Rashid Waseem} \\ Lecturer \\ Business Administration, Art \& Social Sciences \\ University of Education Lahore, Pakistan \\ E-mail: rashid.waseem@ue.edu.pk
}

\begin{abstract}
Commercial banks play an important role for the purpose of sustainable economic development in a country. This paper main theme to presents the comparison of financial performance between private commercial banks in Pakistan during the period of 2015-2019 by using the method of ratio analysis and some other financial indicators. Fourteen Commercial banks out of fifteen banks are selected for comparison of financial analysis. Due to the unavailability of data, the remaining one bank is not chosen for study because, yet they did not publish their final report in 2019. The data of ratio analysis was captured by using the final report of commercial banks, which are available on the bank's official websites. This study provides information about the different ratios which directly impact on bank performance.
\end{abstract}

Keywords: Financial Performance, Commercial Bank, Pakistan, Spread Ratio, ROA, ROE. 


\section{INTRODUCTION}

The financial system is important for business development and economic development of country, as it provides easy access to finance. Commercial banks are the main part of financial system. Commercial banks are financial institutions which work on the base of facility like funds, crafts as their basic. They act as an intermediary between capital and investment. and borrower money from the investor who have access amount to invest (Daiff, 1995). They institution that accept deposit at any time from public and financial institution are known as commercial bank (Shehab, 1987). Financial institution is those institution which works its major operation to collect money to meet the needs of the public and institution in excess for the purpose of lending it to the investor who wants this money (Qazwini, 1989).

The objective of this study is to analyze the comparison between private Commercial banks Performance in Pakistan during the period (2015-2019) on the basis of financial indicators and others measure which have direct relation with banks performance and this study also provide a proper guidelines to investors for the purpose of investment in future. The financial indicator include different types of financial ratio for evaluate the performance such are include Return on Asset (ROA), Return on Equity (ROE), Earning per share (EPS), Spread ratio, investment to total asset ratio, total debt to total asset ratio and other measured also include. The financial ratio is computed through the source of Annual final report which are available on banks official website.

\section{Commercial banks in Pakistan}

Pakistan commercial banking has grown exponentially over the years. In the first years of after independence commercial banks has control by foreign banks. After the period, the situation has changed markedly as a result of both conscious policies to boost the growth of Pakistani banks and structural changes in the economy. Now the banking industry in Pakistan occupy the good position in the form of banking service operation and number of branches .The commercial banking system in Pakistan is play a key role to act as intermediator between investor(who want required money for investment for projects) or saver (who not want to invest money in market and required interest)like the other countries the Commercial banks in Pakistan given different offers in the form of saving scheme to attract the saver and also provide different type of facilities discount trade bills, services render miscellaneous agency, provide remittance facilities and issue guarantees etc.

\section{LITERATURE REVIEW}

Recent year increase the attention, on the topic of measurement especially commercial bank performance (Seiford\&Zhu,1999). The performance of commercial bank has been empirical study all over the world (Tarawneh, 2006; Halkos\&Salamouris, 2004; Webb, 2003; Lacewell, 2003; Yeh, 1996) but unfortunately not much study conduct comparison of banks performance in Pakistan.

Few years ago, generally observe the performance of banks on the base of company size and asset but Tarawneh(2006) says that his study high profitability of banks, that's does not mean always means banks have high total asset, credit, deposit and total capital. Finical performance of the banks also depends on efficiency in operation and asset Management.

Normally, different ways to measure the performance of commercial banks one of them accounting method. (Ncube,2009) says that accounting method, mainly based on the use of financial ratio which are used to assess the banks performance. Sum of different Financial ratio 
has been used to analyze the performance of banks and other financial institution against benchmark and budget or combination of both methodologies (Avkiran, 1995).

Financial ratio analysis (FRA) are used different purpose, these are including check the bank's profitability, indication of business liquidity that's means company ability to cover its debt and check the leverage performance etc. The financial ratio helps to determine the success or comparison between past and recent year result (Lukam,1982). Recent year ago research in Australia that's show the return on asset, interest margin, and capital adequacy ratio are directly impact on customer service (Duncan \& Elliott,2004).

\section{METHODOLOGY}

To complete the research purpose, the data was collected from the Private commercial banks annual financial report as published in the bank's official website. The data was collected for Private commercial banks which are listed by state bank of Pakistan during (2015-2019) which are used to collect the financial ratio and other financial measure. FRA are used to help the comparison between banks performance. Financial ratio can be divided in three parts.

\section{Profitability ratio/Efficiency ratio}

Return on Equity (ROE

Return on Asset (ROA)

Earnings per share (EPS)

Spread Ratio

\section{Liquidity ratio}

Investment to total asset ratio

\section{Solvency ratio}

Total debt to total asset ratio

Other financial measures are:

Total owner Equity

\section{Institution size}

The sample of this study was 14 private commercial banks in Pakistan out of 15 banks and that's representation $93.3 \%$ of population. One commercial bank is not taken as sample because they do not publish their final report in 2019.

\section{RESULT AND ANALYSIS}

Table 1. Return on Equity (ROE)

\begin{tabular}{|l|l|l|l|l|l|l|}
\hline \multicolumn{7}{|c|}{ Value in percentage (\%) } \\
\hline \multirow{3}{*}{ Banks } & \multicolumn{7}{|c|}{ Years } & Average \\
\cline { 2 - 7 } & $\mathbf{2 0 1 5}$ & $\mathbf{2 0 1 6}$ & $\mathbf{2 0 1 7}$ & $\mathbf{2 0 1 8}$ & $\mathbf{2 0 1 9}$ & 13.46 \\
\hline ABL & 16.9 & 14.3 & 11.9 & 12.0 & 12.23 & 14.70 \\
\hline BAL & 15.48 & 13.86 & 13.22 & 15.33 & 15.65 & 18.42 \\
\hline BAHL & 19.5 & 19.09 & 18.5 & 16.9 & 18.15 & 15.13 \\
\hline FBL & 17.63 & 15.60 & 14.44 & 13.43 & 14.57 & \\
\hline
\end{tabular}




\begin{tabular}{|l|l|l|l|l|l|l|}
\hline HBL & 20.64 & 17.47 & 40.90 & 65.84 & 74.78 & 43.92 \\
\hline HBM & 20.78 & 40.46 & 15.11 & 16.64 & 14.88 & 21.57 \\
\hline JS & 13.95 & 12.73 & 5.84 & 3.48 & 0.15 & 7.23 \\
\hline SBL & 3.7 & 4.4 & 5.9 & 5.4 & 5.2 & 4.92 \\
\hline SILK & $(14.83)$ & 5.55 & 9.0 & 9.65 & $(31.42)$ & $(4.41)$ \\
\hline SCB & 15.1 & 15.6 & 13.3 & 17.3 & 22.9 & 16.84 \\
\hline SNBL & 12.56 & 10.30 & 9.02 & 9.78 & 9.98 & 10.32 \\
\hline UBL & 25.7 & 24.9 & 20.6 & 11.6 & 13.8 & 19.32 \\
\hline MCB & 23.21 & 18.94 & 17.65 & 15.48 & 16.84 & 18.42 \\
\hline ASBK & 24.54 & 22.14 & 19.97 & 14.98 & 20.10 & 20.34 \\
\hline
\end{tabular}

Source: Data are collected from the final report of commercial banks official website during the period of (2015-2019).

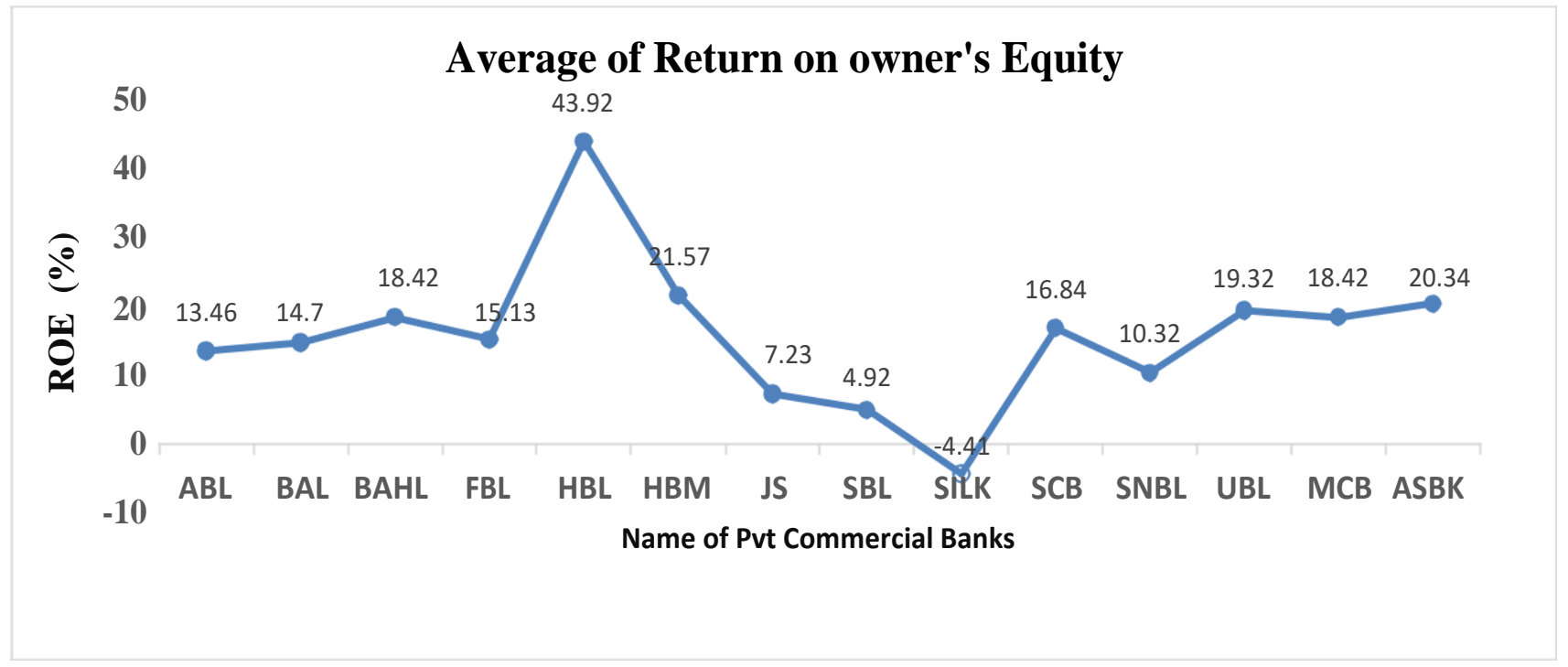

Figure 1. Average of Return on owner's Equity

ROE is basically collected for investors, the purpose of investment that's show the how much level of profit generated against his investment. Table 1 and figure 1 both represent the data of return of equity during the period of 2015 to 2019 and show the five-year average analysis. The average result of five-year analysis shows that HBL has the highest ratio (43.92\%), and the lowest value of roe is silk $(-4.41 \%)$.

Table 2. Return on Asset (ROA)

\begin{tabular}{|c|c|c|c|c|c|c|}
\hline \multicolumn{7}{|c|}{ Value in percentage $(\%)$} \\
\hline \multirow[b]{2}{*}{ Banks } & \multicolumn{6}{|c|}{ Years } \\
\hline & 2015 & 2016 & 2017 & 2018 & 2019 & Average \\
\hline $\mathrm{ABL}$ & 1.5 & 1.3 & 1.0 & 0.9 & 0.9 & 1.12 \\
\hline BAL & 0.93 & 0.88 & 0.87 & 1.11 & 1.26 & 1.01 \\
\hline BAHL & 1.15 & 1.08 & 0.90 & 0.8 & 0.86 & 0.95 \\
\hline
\end{tabular}




\begin{tabular}{|l|l|l|lll|l|l|}
\hline FBL & 1.03 & 0.98 & 0.96 & 0.88 & 0.98 & 0.96 \\
\hline HBL & 1.6 & 1.32 & 0.27 & 0.4 & 0.49 & 0.81 \\
\hline HBM & 1.56 & 1.16 & 0.85 & 0.91 & 0.76 & 1.04 \\
\hline JS & 1.03 & 0.85 & 0.30 & 0.13 & 0.01 & 0.46 \\
\hline SBL & 0.6 & 0.6 & 0.6 & 0.6 & 0.6 & 0.6 \\
\hline SILK & $1.45)$ & 0.55 & 0.75 & 0.77 & $(2.07)$ & $(0.29)$ \\
\hline SCB & 2.2 & 2.1 & 1.7 & 2.1 & 2.7 & 2.16 \\
\hline SNBL & 0.94 & 0.70 & 0.55 & 0.50 & 0.46 & 0.63 \\
\hline UBL & 2.0 & 1.8 & 1.4 & 0.8 & 1.0 & 1.4 \\
\hline MCB & 2.63 & 2.16 & 1.86 & 1.50 & 1.59 & 1.94 \\
\hline ASBK & 1.03 & 0.90 & 0.83 & 0.65 & 0.91 & 0.86 \\
\hline
\end{tabular}

Source: Data are collected from the final report of commercial banks official website during the period of (2015-2019).

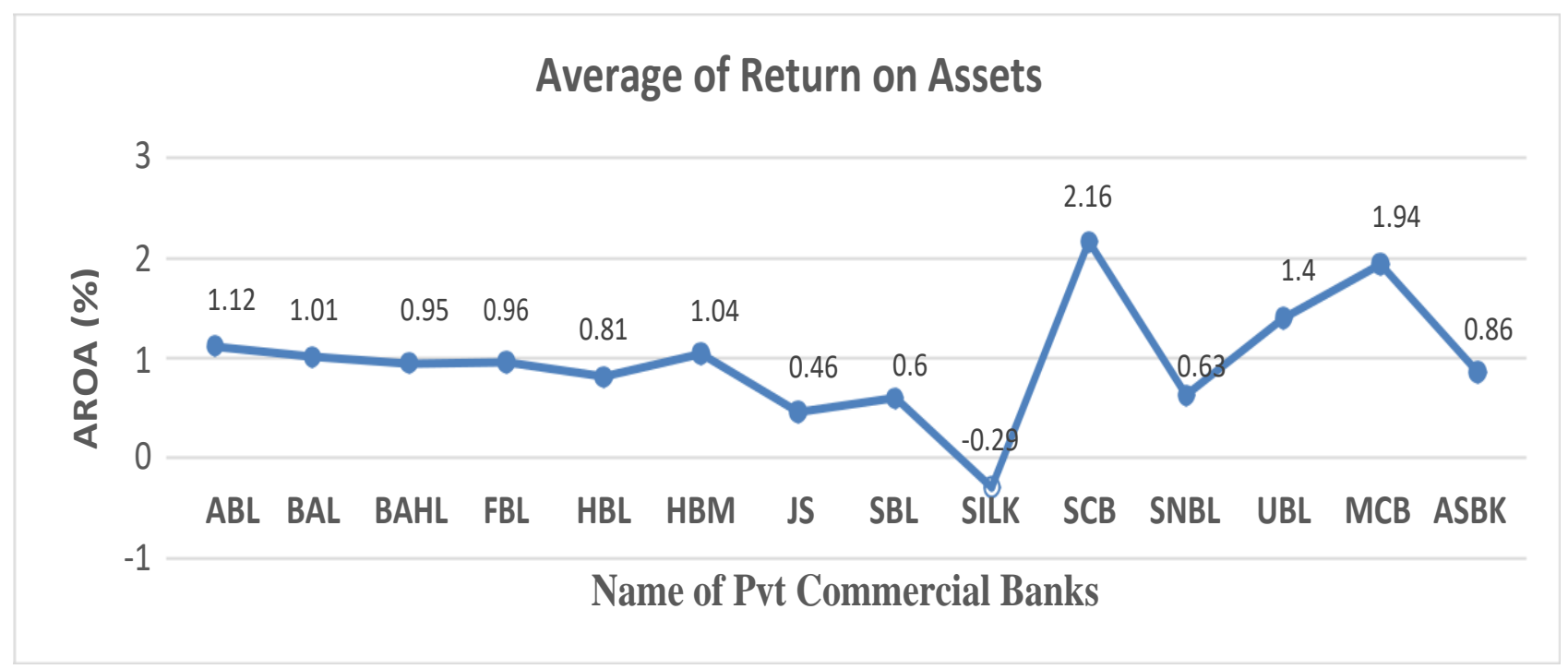

Figure 2. Average of Return on Assets

ROA is basically collected for investors, the purpose of investment that's how much level of profit generate the against the use of bank asset. Table 2 and figure 2 both represent the data of return of Asset during the period of 2015 to 2019 and show the five-year average analysis. The average result of five-year analysis shows that HBL has the highest ratio (2.16\%), and the lowest value of ROA is silk $(-0.29 \%)$.

Table 3. Earnings per share (EPS) RS

\begin{tabular}{|l|l|l|l|l|l|l|}
\hline \multicolumn{7}{|c|}{ Earnings per share (EPS) RS } \\
\hline \multirow{2}{*}{ Banks } & $\mathbf{2 0 1 5}$ & $\mathbf{2 0 1 6}$ & $\mathbf{2 0 1 7}$ & $\mathbf{2 0 1 8}$ & $\mathbf{2 0 1 9}$ & Average \\
\hline ABL & 13.20 & 12.60 & 11.12 & 11.25 & 12.32 & 12.09 \\
\hline BAL & 4.73 & 12.60 & 11.12 & 5.99 & 7.15 & 8.31 \\
\hline
\end{tabular}




\begin{tabular}{|l|l|l|l|l|l|l|}
\hline BAHL & 6.66 & 7.31 & 7.65 & 7.57 & 10.05 & 7.84 \\
\hline FBL & 2.78 & 2.83 & 2.98 & 3.19 & 3.98 & 3.15 \\
\hline HBL & 24.18 & 21.69 & 4.82 & 8.04 & 10.27 & 13.8 \\
\hline HBM & 7.31 & 5.84 & 5.26 & 5.88 & 6.28 & 6.11 \\
\hline JS & 1.74 & 1.77 & 0.74 & 0.30 & 0.0004 & 0.91 \\
\hline SBL & 0.43 & 0.54 & 0.73 & 0.68 & 0.68 & 0.61 \\
\hline SILK & $(0.58)$ & 0.09 & 0.13 & 0.15 & $(0.44)$ & $(0.13)$ \\
\hline SCB & 2.40 & 2.48 & 2.13 & 2.90 & 4.14 & 2.81 \\
\hline SNBL & 2.01 & 1.70 & 1.51 & 1.62 & 1.73 & 1.71 \\
\hline UBL & 21.02 & 22.65 & 22.57 & 12.44 & 15.63 & 18.86 \\
\hline MCB & 22.95 & 19.67 & 18.58 & 18.02 & 20.23 & 19.89 \\
\hline ASBK & 4.00 & 4.14 & 4.18 & 3.52 & 5.57 & 4.28 \\
\hline
\end{tabular}

Source: Data are collected from the final report of commercial banks official website during the period of (2015-2019).

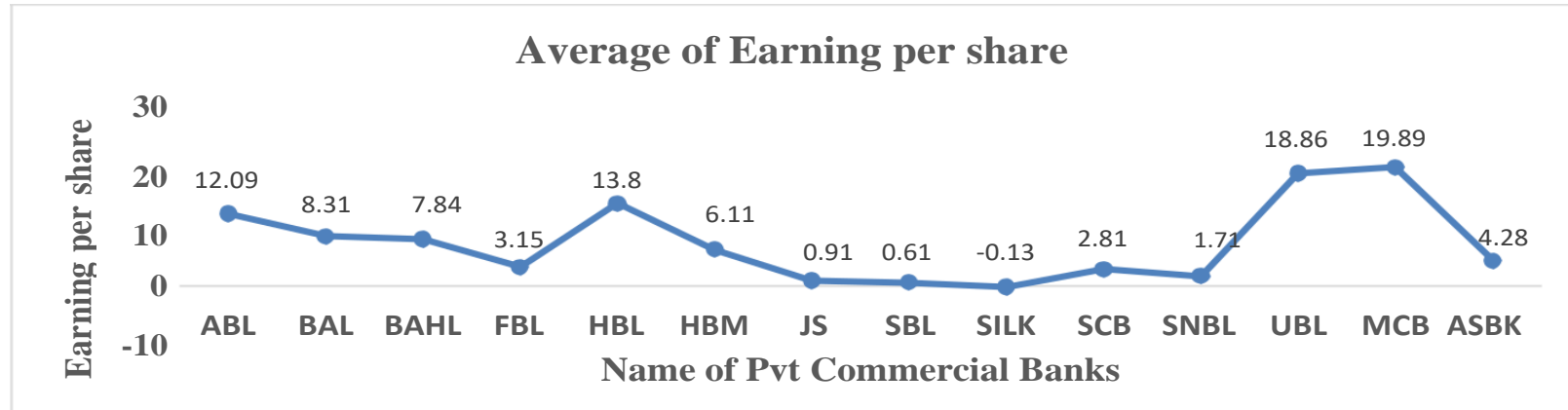

Figure 3. Average of Earning per share

EPS means how much company generates profit in against of each share of its equity. Table 3 and figure 3 both represent the data of earning per share during the period of 2015 to 2019 and show the five-year average analysis. The average result of five-year analysis shows that MCB has the highest ratio (19.89), and the lowest value of EPS is silk (-0.13).

Table 4. Spread Ratio

\begin{tabular}{|l|ll|ll|l|l|}
\hline \multicolumn{7}{|c|}{ Value in percentage (\%) } \\
\hline \multirow{2}{*}{ Banks } & $\mathbf{7}$ & \multicolumn{7}{c|}{ Years } \\
\hline ABL & $\mathbf{2 0 1 5}$ & $\mathbf{2 0 1 6}$ & $\mathbf{2 0 1 7}$ & $\mathbf{2 0 1 8}$ & $\mathbf{2 0 1 9}$ & Average \\
\hline BAL & 50.11 & 51.47 & 48.06 & 43.88 & 33.84 & 45.47 \\
\hline BAHL & 46.60 & 50.73 & 51.58 & 53.26 & 48.50 & 50.13 \\
\hline FBL & 49.34 & 51.61 & 51.53 & 50.87 & 39.00 & 48.47 \\
\hline HBL & 43.19 & 46.05 & 48.44 & 46.24 & 36.16 & 44.01 \\
\hline HBM & 55.08 & 57.56 & 54.47 & 48.37 & 38.39 & 50.77 \\
\hline
\end{tabular}




\begin{tabular}{|l|l|l|l|l|l|l|}
\hline JS & 36.47 & 37.98 & 30.63 & 29.37 & 16.89 & 30.26 \\
\hline SBL & 39.18 & 37.06 & 32.51 & 35.85 & 27.51 & 34.42 \\
\hline SILK & 34.70 & 43.67 & 47.01 & 42.35 & 9.67 & 35.48 \\
\hline SCB & 67.73 & 68.27 & 61.56 & 60.34 & 53.99 & 62.30 \\
\hline SNBL & 41.47 & 39.05 & 34.98 & 32.19 & 20.43 & 33.62 \\
\hline UBL & 59.18 & 58.08 & 52.63 & 49.68 & 40.19 & 51.95 \\
\hline MCB & 61.34 & 65.01 & 57.68 & 55.23 & 43.10 & 56.47 \\
\hline ASBK & 40.72 & 42.11 & 44.66 & 42.62 & 30.89 & 41.00 \\
\hline
\end{tabular}

Source: Data are collected from the final report of commercial banks official website during the period of (2015-2019).

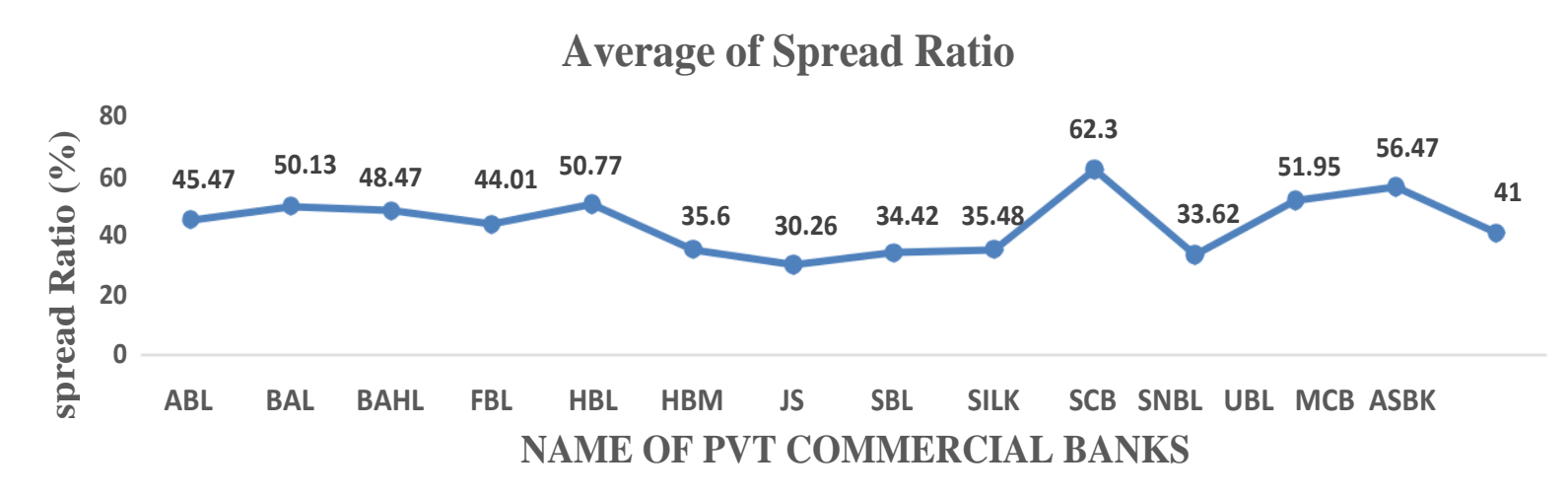

Figure 4. Average of Spread Ratio

Spread ratio of banks obtained through the interest income divide by interest earned. Table 4 and figure 4 both represent the data of spread ratio the period of 2015 to 2019 and show the fiver year average analysis. The average result of five-year analysis show that SCB has the highest ratio $(62.3 \%)$, and the lowest value of JS (30.26\%).

Table 5. Investment to total asset ratio

\begin{tabular}{|l|l|l|l|l|l|l|}
\hline \multicolumn{7}{|c|}{ Value in percentage (\%) } \\
\hline \multirow{2}{*}{ Banks } & $\mathbf{7}$ & \multicolumn{7}{c|}{ Years } \\
\hline ABL & $\mathbf{2 0 1 5}$ & $\mathbf{2 0 1 6}$ & $\mathbf{2 0 1 7}$ & $\mathbf{2 0 1 8}$ & $\mathbf{2 0 1 9}$ & Average \\
\hline BAL & 54.89 & 55.18 & 55.86 & 49.70 & 51.71 & 53.46 \\
\hline BAHL & 46.88 & 41.85 & 40.12 & 27.59 & 28.09 & 36.90 \\
\hline FBL & 55.73 & 52.74 & 50.43 & 39.55 & 45.13 & 48.71 \\
\hline HBL & 45.46 & 37.66 & 36.31 & 35.70 & 32.39 & 37.50 \\
\hline HBM & 58.19 & 54.25 & 51.90 & 46.57 & 44.27 & 51.03 \\
\hline JS & 57.39 & 59.74 & 60.04 & 51.48 & 52.22 & 56.17 \\
\hline SBL & 53.11 & 50.00 & 43.33 & 32.55 & 30.34 & 41.86 \\
\hline
\end{tabular}




\begin{tabular}{|l|l|l|l|l|l|l|}
\hline SILK & 26.68 & 27.76 & 22.93 & 16.65 & 17.62 & 22.32 \\
\hline SCB & 51.82 & 51.78 & 52.42 & 48.44 & 40.18 & 48.92 \\
\hline SNBL & 42.88 & 41.83 & 36.11 & 38.34 & 40.00 & 39.83 \\
\hline UBL & 51.37 & 50.39 & 53.70 & 41.62 & 44.38 & 48.29 \\
\hline MCB & 56.32 & 51.84 & 48.91 & 50.02 & 49.39 & 51.29 \\
\hline ASBK & 50.02 & 47.50 & 47.53 & 36.83 & 42.53 & 44.88 \\
\hline
\end{tabular}

Source: Data are collected from the final report of commercial banks official website during the period of (2015-2019).

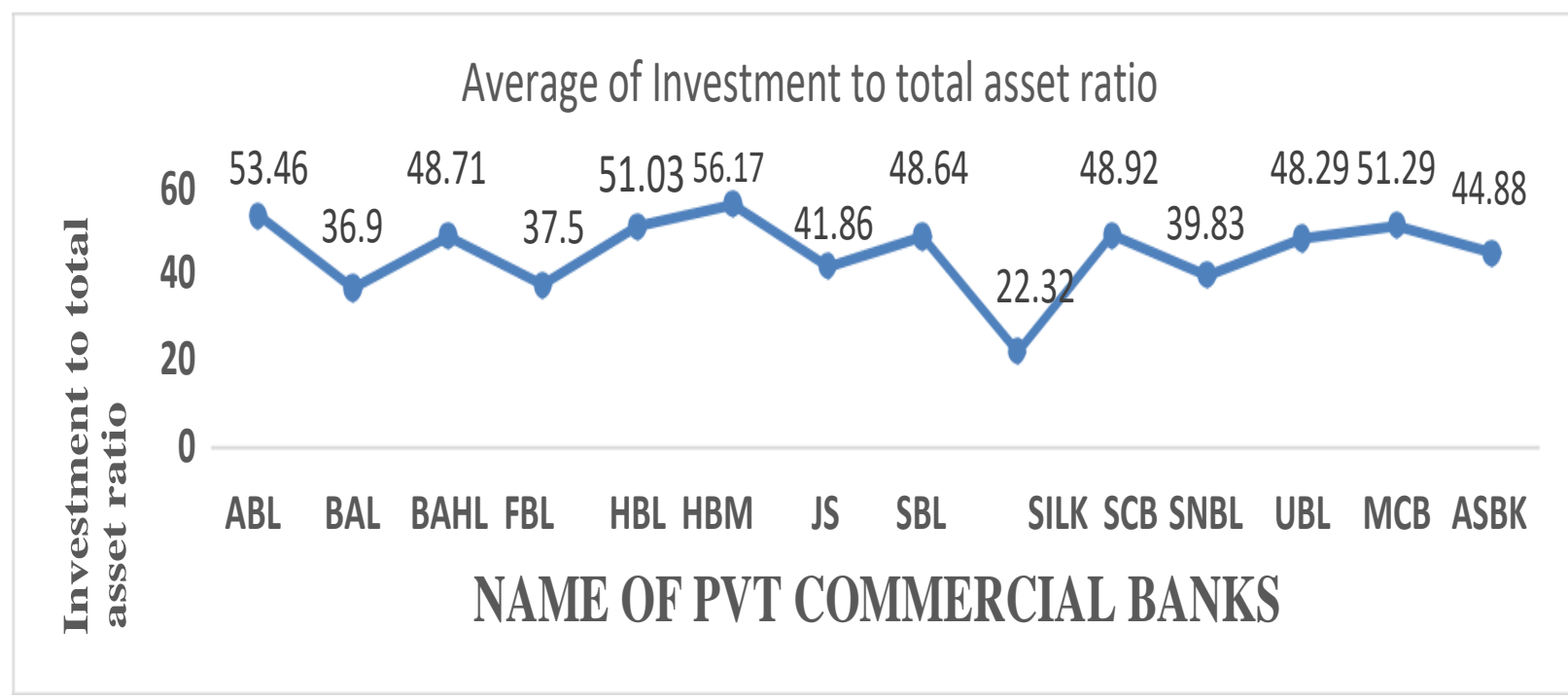

Figure 5. Average of Investment to Total Asset Ratio

Investment to total asset ratio means how much investment contribution on total asset of banks. Table 5 and figure 5 both represent the data of investment to total asset ratio during the period of 2015 to 2019 and show the five-year average analysis. The average result of five-year analysis shows that HBL has the highest ratio (56.17\%), and the lowest value is silk (22.32\%).

Table 6. Total debt to total Assets Ratio

\begin{tabular}{|l|l|l|l|l|l|l|}
\hline \multicolumn{7}{|c|}{ Value in percentage (\%) } \\
\hline \multirow{2}{*}{ Banks } & \multicolumn{7}{|c|}{ Years } \\
\cline { 2 - 8 } & $\mathbf{2 0 1 5}$ & $\mathbf{2 0 1 6}$ & $\mathbf{2 0 1 7}$ & $\mathbf{2 0 1 8}$ & $\mathbf{2 0 1 9}$ & Average \\
\hline ABL & 90.99 & 90.58 & 91.43 & 92.05 & 92.21 & 91.59 \\
\hline BAL & 94.08 & 93.44 & 93.34 & 92.48 & 91.73 & 93.01 \\
\hline BAHL & 94.08 & 94.34 & 95.14 & 95.27 & 95.26 & 94.81 \\
\hline FBL & 92.94 & 92.12 & 92.07 & 92.74 & 91.22 & 92.21 \\
\hline HBL & 91.91 & 92.39 & 93.26 & 93.78 & 93.40 & 92.94 \\
\hline HBM & 92.48 & 92.46 & 93.71 & 94.50 & 94.85 & 93.6 \\
\hline
\end{tabular}




\begin{tabular}{|l|l|l|l|l|l|l|}
\hline JS & 92.69 & 93.75 & 95.70 & 96.58 & 96.31 & 95.00 \\
\hline SBL & 88.00 & 88.66 & 89.15 & 88.30 & 86.27 & 88.07 \\
\hline SILK & 89.05 & 91.07 & 92.10 & 91.85 & 94.76 & 91.76 \\
\hline SCB & 86.15 & 87.09 & 87.70 & 88.32 & 88.23 & 87.49 \\
\hline SNBL & 92.81 & 93.00 & 94.25 & 95.29 & 95.41 & 94.15 \\
\hline UBL & 89.21 & 90.23 & 92.06 & 91.99 & 91.07 & 90.91 \\
\hline MCB & 86.28 & 86.53 & 88.43 & 90.00 & 88.85 & 88.01 \\
\hline ASBK & 94.98 & 94.73 & 95.06 & 95.25 & 94.92 & 94.98 \\
\hline
\end{tabular}

Source: Data are collected from the final report of commercial banks official website during the period of (2015-2019).

\section{Total debt to total Assets Ratio}

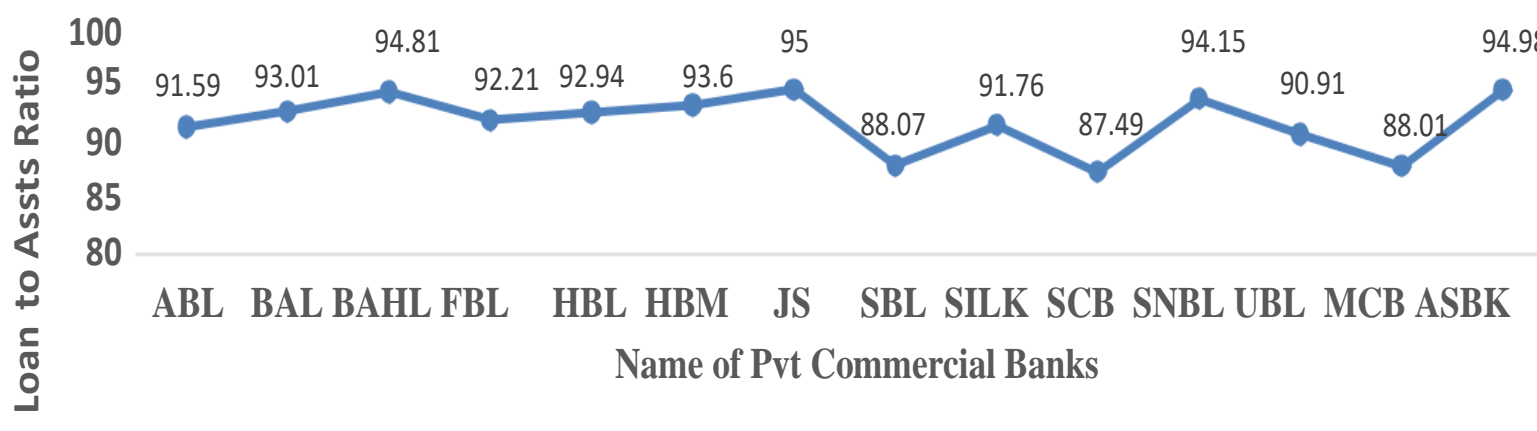

Figure 6. Total Debt to Total Assets Ratio

Source: Data are collected from the final report of commercial banks official website during the period of (2015-2019).

That's ratio show the which banks are stronger according pay its debt obligation. Table 4 and figure 4 both represent the total debt to total asset during the period of 2015 to 2019 and also show the five-year average analysis. The average result of five year analysis show that ASBK has the highest ratio (94.98\%), and the lowest value SCB (87.49\%).

Table 7. Total owners' equity

\begin{tabular}{|l|l|l|l|l|l|l|}
\hline \multicolumn{7}{|c|}{ Value in RS } \\
\hline \multirow{2}{*}{ Banks } & \multicolumn{7}{|c|}{ Years } \\
\cline { 2 - 7 } & $\mathbf{2 0 1 5}$ & $\mathbf{2 0 1 6}$ & $\mathbf{2 0 1 7}$ & $\mathbf{2 0 1 8}$ & $\mathbf{2 0 1 9}$ & Average \\
\hline ABL & $89,256,457$ & $1,006,738,28$ & $106,716,353$ & $107,304,833$ & $115,350,833$ & $103,860,460.8$ \\
\hline BAL & $533,533,175$ & $60,124,762$ & $65,799,740$ & $75,646,875$ & $88,027,576$ & $164,626,425.6$ \\
\hline BAHL & $37,856,658$ & $42,513,744$ & $45,875,882$ & $49,551,680$ & $61,503,110$ & $47,460,214.8$ \\
\hline FBL & $30,352,473$ & $35,008,325$ & $39,246,470$ & $43,498,515$ & $55,263,873$ & $40,673,931.2$ \\
\hline HBL & $171,851,650$ & $182,066,980$ & $172,703,959$ & $179,049,056$ & $201,421,946$ & $181,418,718.2$ \\
\hline HBM & $36,827,804$ & $39,670,450$ & $40,498,255$ & $37,001,956$ & $44,237,530$ & $39,647,199$ \\
\hline
\end{tabular}




\begin{tabular}{|l|l|l|l|l|l|l|}
\hline JS & $15,967,903$ & $16,649,525$ & $16,669,329$ & $15,617,026$ & $17,333,255$ & $16,447,407.6$ \\
\hline SBL & $11,844,219$ & $12,319,524$ & $12,708,194$ & $12,783,755$ & $14,179,487$ & $12,767,035.8$ \\
\hline SILK & $14,576,662$ & $12,054,588$ & $13,181,346$ & $14,386,747$ & $10,771,887$ & $12,994,246$ \\
\hline SCB & $61,950,455$ & $61,282,293$ & $62,936,696$ & $62,238,369$ & $72,916,503$ & $64,264,863.2$ \\
\hline SNBL & $18,191,942$ & $18,289,227$ & $18,504,599$ & $17,988,874$ & $20,213,595$ & $18,637,647.4$ \\
\hline UBL & $142,135,475$ & $151,786,861$ & $159,307,047$ & $151,269,948$ & $169,068,883$ & $154,713,642.8$ \\
\hline MCB & $137,801,938$ & $141,626,625$ & $153,566,377$ & $149,277,729$ & $168,914,783$ & $150,237,490.4$ \\
\hline ASBK & $26,852,943$ & $32,576,950$ & $32,435,491$ & $33,508,907$ & $42,255,844$ & $33,526,027$ \\
\hline
\end{tabular}

Source: Data are collected from the final report of commercial banks official website during the period of (2015-2019).

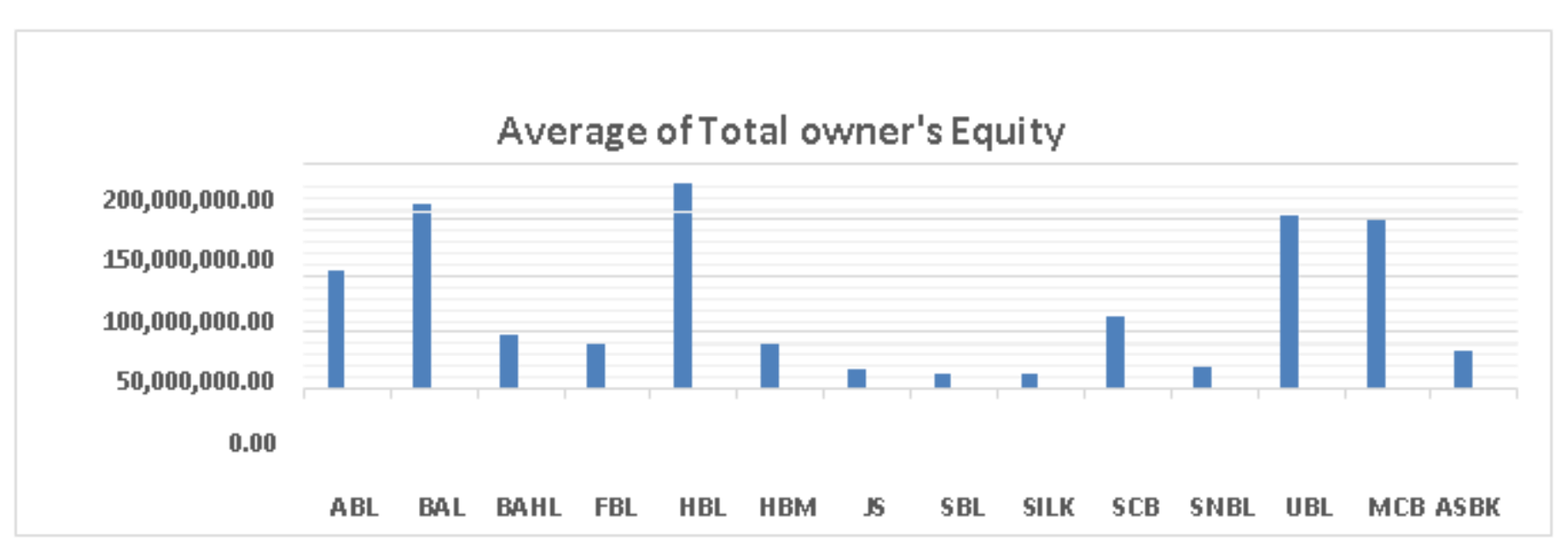

Figure 7. Average of Total owner's Equity

Table 7 and figure 7 both represent the data of Total owner equity during the period of 2015 to 2019 and show the five-year average analysis. The average result of five-year analysis shows that HBL has the highest value of owner equity, and the lowest value of owner equity is SBL.

Table 8. Institution size or Total Assets

\begin{tabular}{|l|l|l|l|l|l|l|}
\hline \multicolumn{7}{|c|}{ Value in RS } \\
\hline \multirow{2}{*}{ Banks } & $\mathbf{2 0 1 5}$ & $\mathbf{2 0 1 6}$ & $\mathbf{2 0 1 7}$ & $\mathbf{2 0 1 8}$ & $\mathbf{2 0 1 9}$ & Average \\
\cline { 2 - 8 } ABL & $9,916,655,12$ & $1,068,945,748$ & $1,245,712,113$ & $1,350,598,909$ & $1,481,121,252$ & $1,227,608,707$ \\
\hline BAL & $902,607,521$ & $917,457,053$ & $988,828,828$ & $1,006,217,843$ & $1,064,672,085$ & $813,956,666$ \\
\hline BAHL & $639,712,468$ & $751,395,816$ & $944,133,780$ & $1,048,239,003$ & $1,298,682,111$ & $936,432,635.6$ \\
\hline FBL & $430,072,860$ & $444,464,661$ & $494,933,882$ & $5,999,914,183$ & $629,852,657$ & $1,599,847,649$ \\
\hline HBL & $2,124,899,508$ & $2,392,699,251$ & $2,563,059,113$ & $2,879,494,859$ & $3,053,733,753$ & $2,602,777,297$ \\
\hline HBM & $489,879,108$ & $526,606,417$ & $644,553,779$ & $673,395,781$ & $859,574,522$ & $638,801,921.4$ \\
\hline JS & $218,475,663$ & $264,700,493$ & $388,308,876$ & $456,754,076$ & $469,820,794$ & $359,611,980.64$ \\
\hline SBL & $80,166,336$ & $101,414,491$ & $117,151,047$ & $122,764,587$ & $129,577,407$ & $110,214,773.6$ \\
\hline SILK & $133,137,259$ & $135,033,822$ & $166,854,532$ & $176,570,999$ & $205,688,080$ & $117,589,431.8$ \\
\hline
\end{tabular}




\begin{tabular}{|l|l|l|l|l|l|l|}
\hline SCB & $447,347,791$ & $474,752,219$ & $513,548,602$ & $576,081,336$ & $619,970,585$ & $526,340,106.6$ \\
\hline SNBL & $253,341,829$ & $278,520,706$ & $322,133,976$ & $382,497,788$ & $442,540,782$ & $335,807,016.2$ \\
\hline UBL & $1,400,650,843$ & $1,577,551,023$ & $2,007,381,446$ & $1,889,599,146$ & $1,893,694,707$ & $1,501,658,433$ \\
\hline MCB & $1,004,410,410$ & $1,051,813,681$ & $1,327,311,040$ & $1,498,130,061$ & $1,515,152,015$ & $1,279,363,441$ \\
\hline ASBK & $535,866,714$ & $619,139,193$ & $656,708,369$ & $706,532,042$ & $833,208,006$ & $670,290,864.8$ \\
\hline
\end{tabular}

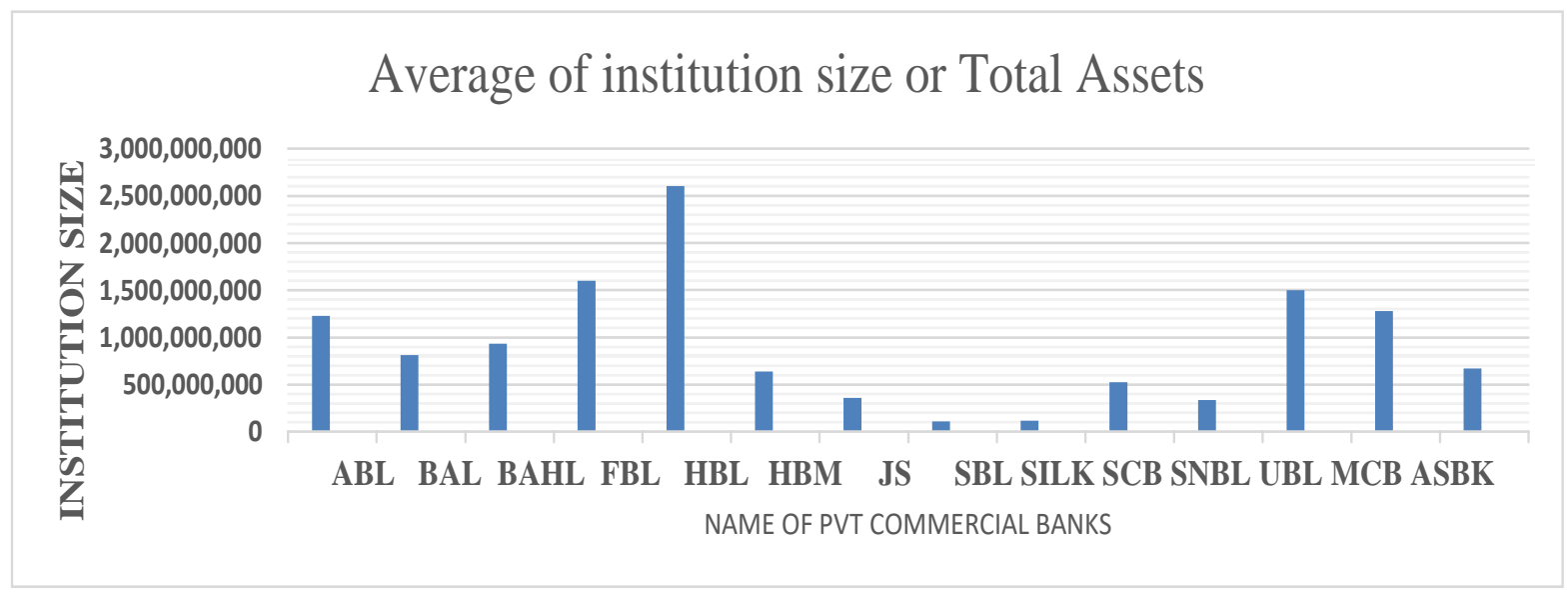

Figure 8. Average of Institution Size or Total Assets

Total asset means the how much banks have own asset. Table 5 and figure 5 both represent the data of Total asset during the period of 2015 to 2019 and show the five-year average analysis. The average result of fiver year analysis shows that HBL has the highest value of asset, and the lowest value of asset is SBL.

\section{LIMITATIONS}

- As compare to other Study this Study also have limitation once of them data was not collected for all Private commercial banks working in Pakistan because Summit banksdata 2019 were not yetupload.

- Accuracy of research depends on the secondary data only which are issued by commercialbanks.

\section{DIRECTIONS FOR FURTHER RESEARCH}

- For the purpose of check the performance of commercial banks used the other methods.

- To check the performance of banks the use of the other reaming ratio.

- Comparison between Islamic and conventional research.

- Covid 19 how the impact of financial performance of banks.

CONCLUSION

This study shows that each commercial bank result is change according to different ratio related to banksperformance.

- According to financial ratio of five year analysis the result of return on equity, in First 
Habib bank limited is at the top, Habib metropolitan bank is the Second, Askari bank is the third, United bank limited is the fourth and BAHL \& MCB is the fifth.

- According to financial ratio of five-year analysis the result of return on assets, SCB is at the top, MCB is the second, UBL is the third, ABL is the fourth and HBM is the fifth.

- According to financial ratio of five-year analysis the result of Earning per share, MCB is at the top, UBL is the second, HBL is the third, ABL is the fourth and BAL is the fifth.

- According to financial ratio of five-year analysis the result of total debt to total asset ratio, JS is at the top, ASBK is the second, BAHL is the third, SNBL is the fourth and HBM is the fifth.

- According to financial ratio of five-year analysis based on institution Size or Total Assets, HBL is at the top, FBL is the second, UBL is the third, MCB is the fourth and $\mathrm{ABL}$ is the fifth.

- According to financial ratio of five-year analysis based on total owner's equity, HBL is at the top, BAL is the second, MCB is the third, UBL is the fourth and ABL is the fifth.

- According to financial ratio of five-year analysis based on investment to total asset ratio, HBM is at the top, ABL is the second, MCB is the third, HBL is the fourth and BAHL is the fifth.

- According to financial ratio of five-year analysis based on Spread Ratio, SCB is at the top, MCB is the second, UBL is the third, HBL is the fourth and BAL is the fifth.

- Finally, we highlight the performance of all the Private commercial banks that's helpful for researcher, investor and managers.

\section{REFERENCES}

Avkiran, N. K. (1995). Developing an instrument to measure customer service quality in branch banking. International Journal of Banks Marketing, 12(6), 10-18.

Daiff, K.(1995). Accounting Commercial Banks, Page 2, Cairo House.

Duncan, E., \& Elliott, G. (2004). Efficiency, customer service and financial performance among Australian financial institutions. International Journal of bank marketing.

Halkos, G. E., \&Salamouris, D. S. (2004). Efficiency measurement of the Greek commercial banks with the use of financial ratios: a data envelopment analysis approach. Management accounting research, 15(2), 201-224.

Lacewell, S. K. (2003). Do efficient institutions score well using ratio analysis? An examination of commercial banks in the 1990s. Academy of Banking Studies Journal, 2, 17.

Luckham, W. R. (1982). Financial Ratio Analysis for Decision-Making. Journal of Arboriculture, 8(11), 296-301.

Ncube, M. (2009). Efficiency of the banking sector in South Africa. University of the Witwatersrand, 1-44.

Qazwini, S.(1989). Lectures Economy of Banks, Court of Publications undergraduate, Algeria, pp. 24.

Seiford, L. M., \& Zhu, J. (1999). Profitability and marketability of the top 55 US commercial banks. Management science, 45(9), 1270-1288.

Shehab, M. (1987). Frozen Money, Banks and Economy. (Mars Publishing House, Riyadh), pp: 105.

Tarawneh, M. (2006). A comparison of financial performance in the banking sector: Some evidence from Omani commercial banks. International Research Journal of Finance and Economics, 3(3), 101-112. 
Webb, R. (2003). Levels of efficiency in UK retail banks: a DEA window analysis. Int. J. of the Economics of Business, 10(3), 305-322.

Yeh, Q. J. (1996). The application of data envelopment analysis in conjunction with financial ratios for bank performance evaluation. Journal of the operational research society, 47(8), 980-988.

\section{APPENDICES}

\section{APPENDIX A: List of Private Commercial Banks}

\begin{tabular}{|c|c|c|}
\hline Name of Private Commercial Banks & Abbreviations & Branches \\
\hline Allied Bank limited & ABL & 1345 \\
\hline Bank Alfalah & BAL & 699 \\
\hline Bank Al Habib & BAHL & 702 \\
\hline Faysal Bank & FBL & 555 \\
\hline Habib Bank Limited & HBL & 1700 \\
\hline Habib Metropolitan Bank & HBM & 400 \\
\hline Js Bank & JS & 238 \\
\hline Samba Bank Limited & SBL & 37 \\
\hline Silk Bank Limited & SILK & 123 \\
\hline Standard Chartered Pakistan & SCB & 61 \\
\hline Soneri bank & SNBL & 300 \\
\hline United Bank Limited & UBL & 1390 \\
\hline Muslim Commercial Bank Limited & MCB & 1400 \\
\hline Askari Bank & ASBK & 350 \\
\hline
\end{tabular}

\section{Copyrights}

Copyright for this article is retained by the author(s), with first publication rights granted to the journal. This is an open-access article distributed under the terms and conditions of the Creative Commons Attribution license (http://creativecommons.org/licenses/by/4.0/) 